\title{
Effect of Ocimum sanctum Leaf Extract on Entero-Insular Axis by Oral Glucose Tolerance Test in Albino Rats
}

\author{
Inbaraj SD*, Muniappan M
}

\section{Inbaraj SD*, Muniappan M}

Department of Pharmacology, Sree Balaji Medical College and Hospital, Bharath Institute of Higher Education and Research [BIHER], Chennai, INDIA.

\section{Correspondence \\ Inbaraj SD}

Department of Pharmacology, Sree Balaji Medical College and Hospital, Bharath

Institute of Higher Education and Research [BIHER], Chennai, INDIA.

E-mail: inbaraj4@yahoo.co.in

History

- Submission Date: 28-06-2019;

- Review completed: 18-07-2019;

- Accepted Date: 22-07-2019.

\section{DOI : 10.5530/pj.2019.11.177}

Article Available online http://www.phcogj.com/v11/i5

Copyright

( $) 2019$ Phcogj.Com. This is an openaccess article distributed under the terms of the Creative Commons Attribution 4.0 International license.

\begin{abstract}
This research study evaluates the effect of Ocimum sanctum leaf extract on the entero-insular axis and the hyperglycemia due to oral glucose tolerance test in albino rats. Methanolic leaf extract of Ocimum sanctum was prepared by Sami labs, Bangalore and used for the study. After obtaining Institutional Animal ethical committee clearance male albino rats (155-215 g) were divided into 4 groups. 6 albino rats were randomly assigned to Control (Normal saline) group, Standard (Vildagliptin $50 \mathrm{mg} / \mathrm{kg}$ ) group, Ocimum sanctum leaf extract $(100 \mathrm{mg} / \mathrm{kg})$ and $(200 \mathrm{mg} / \mathrm{kg})$ groups. After overnight fasting the baseline biochemical evaluation in the fasting state blood glucose, Insulin level, Glucagon level, GLP-1 (Glucagon like peptide-1), GIP (Glucose dependent Insulinotropic peptide) level were measured for all the above groups. Control, Vildagliptin (STD) and the extracts were orally administered by using rat oral feeding tube. 30 minutes later oral glucose tolerance test (OGTT) was done. Blood samples were evaluated for blood sugar, Insulin, Glucagon, GLP-1 and GIP at 0, 15 and 45 minutes after oral glucose load. Ocimum sanctum $(200 \mathrm{mg} / \mathrm{kg})$ showed significant $(\mathrm{p} \leq 0.05)$ reduction in blood glucose at 45 minutes when compared to control. Ocimum sanctum $(100 \mathrm{mg} / \mathrm{kg} \mathrm{\&} 200 \mathrm{mg} / \mathrm{kg})$ showed significant $(\mathrm{p} \leq 0.001)$ increase in GIP levels at 45 minutes of OGTT. Ocimum sanctum leaf extract showed significant antihyperglycemic and incretin enhancing effects. Further indepth animal and clinical studies are necessary to demonstrate the therapeutic potential of this extract for the treatment of type 2 diabetes mellitus.
\end{abstract}

Key words: Ocimum sanctum, Entero-Insular axis, Antihyperglycemic, Insulin, Glucagon.

\section{INTRODUCTION}

Incidence of diabetes is increasing day by day in India and around the world. Hence most of the research studies are directed towards diabetes especially the pathophysiology and treatment aspects of type 2 diabetes mellitus. International Diabetes federation data shows currently 366 million people are suffering from diabetes and this may increase twice in number by $2030 .{ }^{1}$ In India type 2 diabetes mellitus presentation is postprandial hyperglycemia attributed to high carbohydrate consumption. Medical nutrition therapy along with herbals ingredients may control hyperglycemia, hyperlipidemia and arrest the micro and macro vascular complications of diabetes mellitus. ${ }^{2}$ Dietary polyphenols has antihyperglycemic activity by acting on the beta cells and insulin resistance. ${ }^{3}$

In India more than $75 \%$ of the diet consists of carbohydrates. ${ }^{4}$ To tide over this problem inclusion of edible herbs in diet may reduce carbohydrate absorption from gut and act in the entero-insular axis by enhancing incretins and Insulin. ${ }^{5}$ This is an interesting area of research which may be explored in future. In the current study we evaluated the anti hyperglycemic and incretin enhancing effect of commonly used edible herbal Ocimum sanctum leaf extract on the entero-insular axis in albino rats. Ocimum sanctum is a common herb belongs to family- Labiatae locally known as Tulsi and Holy basil is widely used in the Indian system of medicine. Each and every part of the plant has enormous medicinal property. ${ }^{5}$ It has diaphoretic and expectorant effect and used to relieve headache, dermatological diseases. The antidiabetic property of Ocimum sanctum leaves has been demonstrated in diabetic rats. ${ }^{6,7}$ Ocimum sanctum leaf extracts also has a-glucosidase inhibitory activity and antidiabetic activity in in-vitro and in-vivo studies. ${ }^{8,9}$ This research is undertaken to through some light on the role of Ocimum sanctum on emerging pharmacotherapy of type 2 diabetes.

\section{MATERIALS AND METHODS}

This is a randomized controlled study with animals (albino rats) to evaluate the antihyperglycemic effect of leaf extract of Ocimum sanctum by using approved Oral glucose tolerance test (OGTT). It evaluates the hyperglycemic and consequent hormonal influences of OGTT on the entero-insular axis.

Institutional research committee and animal ethical committee approval (Protocol No.002/09/2015/ IAEC/SBMCH) obtained through proper channel. The extract was manufactured and supplied by Sami labs Limited, Bangalore. Product Code 2045, Batch No. C170698EM. Date of manufacture April 2017. Ocimum sanctum (Tulsi) methanolic leaf extract was used for this study. Physical, Chemical and Microbiological testing for the above extract was done and certificate of analysis was issued by

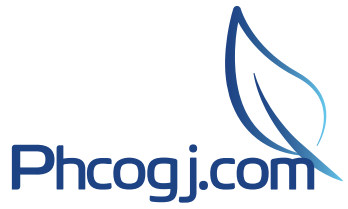

Cite this article: Inbaraj SD, Muniappan M. Effect of Ocimum sanctum Leaf Extract on EnteroInsular Axis by Oral Glucose Tolerance Test in Albino Rats. Pharmacog J. 2019;11(5):1138-42. 
the Sami Labs Limited. T. Vildagliptin $50 \mathrm{mg}$ was obtained from the local pharmacy, powdered and made into a suspension $(10 \mathrm{mg} / \mathrm{ml})$ and administered to rats by oral feeding tube. ${ }^{10}$

Male and female albino rats (weighing 150-250 grams) total 70 numbers were purchased from King Institute, Guindy, Chennai. The rats were provided with a commercial diet and maintained under controlled temperature, humidity, and lighting $\left(22 \pm 2^{\circ} \mathrm{C}, 55 \pm 5 \%\right)$ and a 12-hr light/dark cycle with lights on at 7:00 AM. All procedures were conducted according to the CPCSEA (Committee for the Purpose of Control and Supervision of Experiments on Animals) guidelines and as per the Animal ethical Committee regulations. ${ }^{11}$

\section{Preliminary acute toxicity}

Single oral dose of $2000 \mathrm{mg} / \mathrm{kg}$ for the extract groups of 6 albino rats (3 males and 3 females in each group) weighing $155-215$ gm. ${ }^{12}$ Similarly, one control group of 6 rats was administered with distilled water (1 $\mathrm{ml} / 100 \mathrm{~g}$ ) orally. The animals were observed for clinical manifestations and mortality for first 6 hours and then for next 14 days. The results and conclusion is that the single oral dose of $2000 \mathrm{mg} / \mathrm{kg}$ Ocimum santum leaf extract did not cause death or any abnormal clinical manifestations in male or female rats.

The effective dose was arrived at by studying previous similar research articles. 2 dose levels (low and high) were chosen for the extract. Ocimum sanctum leaf extract $100 \mathrm{mg} / \mathrm{kg}$ (low dose) and $200 \mathrm{mg} / \mathrm{kg}$ (High dose). Vildagliptin (Standard drug) (50/kg ). ${ }^{13,14}$

\section{Grouping of animals}

Male albino rats (155-215 g) were randomly divided into 4 groups each having 6 albino rats as follows:

- Group1: control (Normal saline $1 \mathrm{ml} / 100 \mathrm{~g}$ ) group ( $\mathrm{n}=6$ )

- Group 2: Standard (Vildagliptin $50 \mathrm{mg} / \mathrm{kg})$ group $(\mathrm{n}=6)$

- Group 3: Ocimum sanctum (Low dose $100 \mathrm{mg} / \mathrm{kg})(\mathrm{n}=6)$

- Group 4: Ocimum sanctum (High dose 200/kg) $(\mathrm{n}=6)$

\section{Procedure}

After overnight fasting the baseline biochemical evaluation such as fasting blood glucose, Insulin, Glucagon, GLP-1 and GIP blood levels were estimated for all the 4 groups.

The extract of Ocimun sanctum (Low dose $100 \mathrm{mg} / \mathrm{kg}$ ) and (High dose $200 \mathrm{mg} / \mathrm{kg}$ ), Vildagliptin $50 \mathrm{mg} / \mathrm{kg}$, and control (Normal saline $1 \mathrm{ml} / 100 \mathrm{gm}$ ) were administered orally to the respective groups of rats using rat feeding tube. 30 minutes later oral glucose load (dose $2.2 \mathrm{gm} /$ $\mathrm{kg}$ ) was administered by oral feeding tube to all animals as per the PTGO protocol. ${ }^{15}$ Blood samples were collected at $0,15,45$ minutes after oral glucose load from the tail vein of the rat $(0.2-0.25 \mathrm{ml})$ and transferred into heparinized tubes. Blood glucose test and hormonal assays (Insulin, Glucagon, GLP-1 and GIP) were performed as per the procedure. $^{16}$

The Biochemical and hormonal assays were carried out in Aaranya Biosciences Pvt. Ltd, SIPCOT, Siruseri, Navalur. Hormonal assay kits were purchased from Hysel India Pvt. Ltd. (Manufacturer Raybiotech Inc, USA. Insulin- ELR-Insulin-2 Ray $\mathrm{Bio}^{\circ}$ rat Insulin ELISA Kit. Glucagon-EIAR-GLU-2 Ray Bio ${ }^{\circ}$ rat Glucagon EIA kit. GLP-1 : EIAR -GLP-1 Ray Bio ${ }^{\circ}$ rat GLP-1 EIA kit. GIP- EIAR-GIP-1 -Ray Bio ${ }^{\circ}$ rat GIP -EIA Kit.

\section{Blood glucose determination}

Blood samples were collected as per the approved blood collection techniques for laboratory animals. Institutional animal ethical committee permission obtained to collect blood with 7 appropriate technique. ${ }^{17}$ Blood samples $(0.2-0.25 \mathrm{ml})$ were collected from the rat tail vein at 0,15 and 45 minutes. It was mixed with $140 \mu \mathrm{l}$ of $0.6 \mathrm{M}$ perchloric acid. After centrifugation, the supernatants were assayed for glucose using an enzymatic assay kit.

\section{Plasma insulin, GLP-1, GIP determination:}

Approximately $250 \mu \mathrm{l}$ of blood samples were collected from the tail $\operatorname{vein}^{18}$ at 0,15 and 45 minutes of the test in the heparinized capillary tubes. After centrifugation, supernatants were assayed for plasma insulin, glucagon, active GLP-1 and GIP levels. ${ }^{19}$

Plasma insulin and glucagon levels were determined using a commercial enzyme-linked immunosorbent assay (ELISA) kit. Plasma active GLP1\& GIP levels were determined using an ELISA kit [GLP-1) Active ELISA kit. ${ }^{20}$

\section{Statistical analysis}

Biochemical and hormonal test result data are expressed as the mean \pm S.E.M. Differences in the values of blood glucose in an OGTT between the groups treated with control, standard drug and the extract of 2 doses were determined by one-way ANOVA, followed by Dunnett's multiple comparison test.

The data of plasma insulin, Glucagon, GLP-1 and GIP values at 0,15 and 45 min were compared with the standard drug Vildagliptin. The data were analyzed using one-way ANOVA, followed by Dunnett's multiple comparison test. $p$ value of $<0.05$ (two-sided) was considered statistically significant. Statistical analyses were performed using Graph Pad software (Prism Windows 5). ${ }^{21}$

\section{RESULTS AND DISCUSSION}

Tables 1-3.

Table 1: Effect of Ocimum sanctum leaf extract on Glucose tolerance test in albino rats.

\begin{tabular}{|c|c|c|c|c|}
\hline \multirow{2}{*}{$\begin{array}{c}\text { Groups }(n=6) \\
\text { Groups }\end{array}$} & \multicolumn{4}{|c|}{ Blood glucose level } \\
\hline & $\begin{array}{c}-30 \text { mts } \\
\pm S D(n=6)\end{array}$ & $\begin{array}{c}0 \text { mts } \\
\pm S D(n=6)\end{array}$ & $\begin{array}{c}15 \mathrm{mts} \\
\pm \mathrm{SD}(\mathrm{n}=6)\end{array}$ & $\begin{array}{c}45 \text { mts } \\
\pm S D(n=6)\end{array}$ \\
\hline Control & $76.4 \pm 6$ & $77.5 \pm 9.1$ & $176.7 \pm 9.6$ & $118.2 \pm 8.8$ \\
\hline VG (50 mg/kg) & $77.1 \pm 2$ & $76 \pm 6.0$ & $119 \pm 4.5^{\star * *}$ & $113 \pm 11.8$ \\
\hline OS (100 mg/kg) & $72.2 \pm 15$ & $72.5 \pm 17.4$ & $168 \pm 11.9$ & $142 \pm 4.3$ \\
\hline OS (200 mg/kg) & $73.3 \pm 16$ & $72.5 \pm 17.1$ & $155.5 \pm 7.7^{\star}$ & $120.5 \pm 7.3$ \\
\hline
\end{tabular}

Vildagliptin VG (STD $50 \mathrm{mg} / \mathrm{kg}$ ) shows significant reduction in blood glucose ( $\mathrm{p} \leq 0.001$ ) at $45 \mathrm{~min}$ and Ocimum sanctum (OS $200 \mathrm{mg} / \mathrm{kg}$ ) shows significant reduction in blood glucose $(\mathrm{p} \leq 0.05)$ at 15 minutes of OGTT when compared to the control. (Refer Table -1 and Graph -1). 
Table 2: Effect of Ocimum sanctum on GLP-1, GIP on Glucose tolerance test in albino rats.

\begin{tabular}{|c|c|c|c|c|c|c|c|c|}
\hline \multirow{2}{*}{$\begin{array}{l}\text { Parameter } \\
\text { STD (mean n } \\
=6 \text { ) } \\
\text { Groups }\end{array}$} & \multicolumn{4}{|c|}{$\begin{array}{l}\text { GLP-1 (pg/ml) } \\
\text { Time (minutes) }\end{array}$} & \multicolumn{4}{|c|}{$\begin{array}{c}\text { GIP (pM) } \\
\text { Time (minutes) }\end{array}$} \\
\hline & -30 & 0 & 15 & 45 & -30 & 0 & 15 & 45 \\
\hline Control & $14 \pm 1$ & $15 \pm 0.2$ & $31 \pm 0.4$ & $16 \pm 0.4$ & $10 \pm 1$ & $10 \pm 0.5$ & $63 \pm 2.4$ & $15 \pm 0.7$ \\
\hline VG(50 mg/kg) & $15 \pm 0.5$ & $16 \pm 0.5$ & $45 \pm 2.0^{*}$ & $26 \pm 18.3$ & $11 \pm 1$ & $10 \pm 0.2$ & $60 \pm 0.7$ & $24 \pm 1.4^{\star * \star}$ \\
\hline OS (100 mg/kg) & $15 \pm 1$ & $15 \pm 0.6$ & $39 \pm 0.4$ & $21 \pm 13$ & $9 \pm 0.1$ & $9 \pm 0.3$ & $60 \pm 3.5$ & $42 \pm 2.1^{* * *}$ \\
\hline OS (200 mg/kg) & $14 \pm 0.1$ & $13 \pm 0.2$ & $27 \pm 2.9$ & $22 \pm 16$ & $8 \pm 0.2$ & $8 \pm 0.4$ & $55 \pm 4.6$ & $30 \pm 2.8^{* * *}$ \\
\hline
\end{tabular}

${ }^{* * *} \mathrm{p} \leq 0.001 ;{ }^{*} \mathrm{p}=0.05$; Values are STD mean $(\mathrm{n}=6)$ VG- Vildagliptin, OS- Ocimum sanctum.

Vildagliptin $(50 \mathrm{mg} / \mathrm{kg})$ shows significant increase in GIP $(\mathrm{p} \leq 0.001)$ at 45 minutes and increase in GLP-1 $(\mathrm{p} \leq 0.05)$ when compared to the control. Ocimum sanctum $(100 \mathrm{mg} / \mathrm{kg} \& 200 \mathrm{mg} / \mathrm{kg}$ ) shows significant $(\mathrm{p} \leq 0.001)$ increase in GIP levels at 45 minutes of OGTT.

Table 3: Effect of Ocimum sanctum on Insulin and Glucagon during Glucose tolerance test in albino rats.

\begin{tabular}{|c|c|c|c|c|c|c|c|c|}
\hline \multirow{2}{*}{$\begin{array}{c}\text { Parameter STD } \\
\text { (mean } \mathrm{n}=6 \text { ) } \\
\text { Groups }\end{array}$} & \multicolumn{4}{|c|}{$\begin{array}{l}\text { Insulin (ng/ml) } \\
\text { Time (minutes) }\end{array}$} & \multicolumn{4}{|c|}{$\begin{array}{l}\text { Glucagon (pmol/L) } \\
\text { Time (minutes) }\end{array}$} \\
\hline & -30 & 0 & 15 & 45 & -30 & 0 & 15 & 45 \\
\hline Control & $0.2 \pm 1$ & $0.2 \pm 0.01$ & $3 \pm 0.1$ & $1 \pm 0.04$ & $6.3 \pm 1$ & $6.4 \pm 0.07$ & $3.7 \pm 0.1$ & $2.4 \pm 0.07$ \\
\hline VG(50 mg/kg) & $0.21 \pm 1$ & $0.2 \pm 0.0$ & $4 \pm 0.2^{* * *}$ & $3 \pm 0.07^{\star * *}$ & $5.8 \pm 1$ & $5.9 \pm 0.1$ & $4.3 \pm 0.3$ & $3 \pm 0.2$ \\
\hline OS (100 mg/kg) & $0.2 \pm 0.2$ & $0.2 \pm 0.03$ & $0.6 \pm 0.1$ & $1 \pm 0.3$ & $6.2 \pm 0.1$ & $6.1 \pm 0.4$ & $3.3 \pm 0.07$ & $2.4 \pm 0.04$ \\
\hline OS (200 mg/kg) & $0.20 \pm 1$ & $0.20 \pm 0.1$ & $1 \pm 0.08$ & $1 . .3 \pm 0.1$ & $5.8 \pm 1$ & $5.9 \pm 3$ & $3 \pm 0.3$ & $2.5 \pm 0.6$ \\
\hline
\end{tabular}

Values are STD mean $(n=6)$ VG-Vildagliptin, OS-Ocimum sanctum.

Vildagliptin $(50 \mathrm{mg} / \mathrm{kg})$ shows significant increase in Insulin level $(\mathrm{p} \leq 0.001)$ at 15 and 45 minutes when compared to control. Ocimum sanctum does not show any increase in insulin or glucagon level when compared to the control.

\section{DISCUSSION}

Since olden days herbs play an important role in the treatment of diabetic patients. Even the modern allopathic drugs are derived from plant sources. Most of the research studies are done to evaluate the antidiabetic activity of herbals. Our study is carried out with the aim of evaluating the effect of edible herbals on entero-insular axis. Edible herbs are wonderful agents which has the potential to stimulate the incretins and control the blood sugar through the entero-insular axis which is clearly demonstrated in our study. ${ }^{22}$ Vildagliptin (STD $50 \mathrm{mg} / \mathrm{kg})$ and Ocimum sanctum $(200 \mathrm{mg} / \mathrm{kg})$ showed significant reduction in blood glucose $(\mathrm{p} \leq 0.001)$ and $(\mathrm{p} \leq 0.05)$ respectively at 15 minutes of OGTT (Table 1) when compared to control. This reference study also demonstrates the antihyperglycemic effect of Ocimum sanctum on oral glucose as well as oral sucrose tolerance test. The antihyperglycemic effect of Ocimum sanctum was demonstrated also in type 2 diabetic rat model in comparison with Glibenclamid. ${ }^{23}$ Probably this antihyperglycemic action of Ocimum sanctum is mediated through entero insular axis.

Vildagliptin $(50 \mathrm{mg} / \mathrm{kg})$ showed incretin enhancing effect by increasing GLP-1 ( $p \leq 0.05)$ after 15 minutes and GIP ( $p \leq 0.001)$ at 45 minutes of OGTT (Table 2). A similar study showed increase in GLP-1 level at 5 minutes after OGTT. ${ }^{24}$ In our study the Vildagliptin shows increase in GLP-1 level at 15 minutes of OGTT and there is significant increase in GIP levels ( $\mathrm{p} \leq 0.001)$ at 45 minutes of OGTT for Ocimum sanctum $(100 \mathrm{mg} / \mathrm{kg}$ and $200 \mathrm{mg} / \mathrm{kg}$ ), Vildagliptin group when compared to the control (Table 2). The Ocimum sanctum leaf extract at low and high doses showed significant increase in GIP levels $(\mathrm{p} \leq 0.001)$ at 45 minutes of OGTT (Table 2). This is an important observation in our study to prove that it is having effect on the entero-insular axis. It may be due to direct stimulatory effect on the G cells of intestine to secret GIP or it may be due to inhibition of DPP IV enzyme inhibition and enhancing the GIP level. ${ }^{25}$ An in-vitro study done on the pancreatic beta cells showed that GIP has mitogenic and anti-apoptotic factor effect on beta cells. ${ }^{26} \mathrm{Hence}$ Ocimum sanctum leaf extract may also have the mitogenic and beta cell proliferating action through GIP. However further in depth research will through light on this effect. Though many studies demonstrated insulin secretary action of Ocimum sanctum, ${ }^{27}$ this study could not demonstrate any effect on insulin or glucagon secretion.

\section{CONCLUSION}

Ocimum sanctum leaf extract shows significant antihyperglycemic and incretin enhancing effects through entero-insular axis. Further scientific and clinical studies are necessary to establish the therapeutic potential of the extract in the treatment of type 2 diabetes mellitus.

\section{ACKNOWLEDGEMENT}

I thank Prof. M. Muniappan, Professor of Pharmacology, Sree Balaji Medical college and Hospital, BIHER for guiding me to undertake the research. I gratefully acknowledge Sami labs limited, Bangalore for supplying the extracts free of cost and encouraged me to do research.

\section{CONFLICTS OF INTEREST}

Conflicts of interest declared none.

\section{AUTHORS CONTRIBUTION STATEMENT}

Prof. M. Muniappan conceived the idea and guided me in conducting this research study and also reviewed themanuscript. Dr. S. D. Inbaraj myself carried out the research study, evaluated the results and written the manuscript.

\section{REFERENCES}

1. International diabetes federation. IDF SEA members: India. https://www.idf.org

2. Patel DK, Kumar R, Laloo D, Hemalatha S. Natural medicines from plant sources used for therapy of diabetes mellitus: An overview of its pharmacological aspects. Asian Pacific Journal of Tropical Disease. 2012;139-250.

3. Bahadoran Z, Mirmiran P, Azizi F. Dietary polyphenols as potential nutraceuticals in management of diabetes: A review. 2013;12:43.

4. Mohan V, Radhika G, Sathya RM, Tamil SR, Ganesan A, et al. Dietary carbohydrates, glycemic load, food groups and newly detected type 2 diabetes among urban Asian in Chennai, India (Chennai Urban Rural Epidemiology Study 59). Br J Nutr. 2009;102(10):1498-506.

5. Satyavati GV, Gupta AK, Bhatla N. Ocimum santum Linn (Lamiaceae: Labiateae). In Medicinal plants of India (Indian Council of Medical Research, New Delhi). 1987;354

6. Chattopadhyay RR. Hypoglycemic effect of Ocimum sanctum leaf extract in normal and streptozotocin diabetic rats. Indian Journal of Experimental Biology. 1993;31(11):891-3. 
7. Sarkar A, Pant MC. A comparative study of hypoglycemic action of seeds and fresh leaves of Ocimum sanctum (Tulsi). Indian Journal of Physiology and Pharmacology. 1989;33(3):197.

8. Smita K, Manjunath K, Sarangi S. Evaluation of $\alpha$-Glucosidase inhibitory potential of methanolic leaf extrac of Ocimum canum. Int J Pharm Pharm Sci. 2018;10(1):126-31

9. Dimple S, Kumar A, Kumar V, Tomer V. Traditional medicinal systems for treatment of diabetes mellitus: A review. Int J Pharm Pharm Sci. 2018;10(5):717.

10. Wang X, Zhang D, Xu W, Liu H, Wang W. Pharmacokinetics of lipoyl vildagliptin a novel dipeptidyl peptidase IV inhibitor after oral administration in rats. Xenobiotic. 2010;40(10):707-12.

11. CPCSEA guidelines for laboratory animal facility. Indian Journal of Pharmacology. 2003;36:267-74

12. Gopi S, Jacob J, Mathur KY. Acute and subchronic oral toxicity studies of hydrogenated curcuminoid formulation CuroWhite in rats. Toxicol Rep. 2016:(3):817-25.

13. Zhang D, Fu M, Gao S, Lin J. Curcumin and diabetes: A systematic review. Evid Based Complement Alternat Med. 2013;636053:16.

14. Jarald E, Bangar O, Edwin S, Ahmad S, Jamalludin S. Antidiabetic activity of few Indian medicinal plants vs their combination in Alloxan induced diabetic rats. J Pharm Res. 2009:2(11):1760-3.

15. Chaimum-aom N, Chomko S, Talubmook C. Toxicology and oral glucose tolerance test (OGTT) of Thai medicinal plant used for diabetes control, Phyllanthus acidus L. (EUPHORBIACEAE). Pharmacogn J. 2017;9(1):58-61.

16. Raylene A, Russell JC. Glucose tolerance, lipids and GLP-1 secretion in JCR: LA-cp. Rats fed a high protein fiber diet. Obesity. 2008;16(1).

17. Parasuraman $S$, Raveendran $R$, Kesavan R. Blood sample collection in small laboratory animals. J Pharmacol Pharmacother. 2010;1(2):87-93.
18. Yamazaki K, Yasuda N, Inoue T, Nagakura T, Kira K, Shinoda M, et al. 7-But2-ynyl-9-(6-methoxy-pyridin-3-yl)-6-piperazin-1-yl-7,9-dihydro-purin-8-one is a novel competitive and selective inhibitor of dipeptidyl peptidase iv with an antihyperglycemic activity. J Pharmacol Exp Ther. 2006;319(3):1253-7.

19. Sheldon B, Russel Jones D, Wright J. Insulin analogues: An example of applied medical science. Diabetes Obes Metab. 2009;11:5-19.

20. Elliot AD, Ustione A, Pisto DW. Somatostatin and Insulin mediate glucoseinhibited glucagon secretion in the pancreatic cell by lowering CAMP. Am J Physiol Endocrinol Metab. 2015;308(2):E130-43.

21. Dean R. Appling, software review of prism 5. J Am Chem Soc 2008;130(18):6056.

22. Hannan JMA, Ojo OO, Ali L, Rokeya B, Khaleque J, Ahter M, et al. Actions underlying antidiabetic effects of Ocimum sanctum leaf extracts in animal models of type 1 and type 2 Diabetes. European J Med Plants. 2015;5(1):1-12.

23. Kumar Nim D, Shankar P, Chaurasia R, Goel B, Dixit RK. Clinical evaluation of anti-hyperglycemic activity of Ocimum sanctum in comparison with Glibenclamide in the rat model of T2DM. Int J Pharm Bio Sci. 2013:4(2):699706 .

24. Burkey BF, Li X, Bolognese L, Balkan B, Mone M, Russell M, et al. Acute and chronic effect of the incretin Enhancer Vildagliptin in insulin resistant rats. The J Pharmacol Exp Ther. 2005:315(2):688-95.

25. Singh AK, Jatwa R, Joshi J. Cytoprotective and dipeptidyl peptidase IV (DPP-IV/ CD26) inhibitory roles of Ocimum sanctum and Momordica charantia extract. Asian J Pharm Clin Res. 2014;7(1):115-20.

26. Trumper TK, Horsch D. Mechanisms of mitogenic and anti-apoptotic signaling by glucose -dependent insulinotropic polypeptide in beta (INS-1)- cells. J Endocrinol. 2002;174(2):233-46

27. Hannan JMA, Marenah I, Ali L, Rokeya B, Flatt PR, Abdel-Wahab YHA. Ocimum sanctum leaf extracts stimulate insulin secretion from perfused pancreas, isolated islets and clonal pancreatic ß-cells. J Endocrinol. 2006;189;127-36.

\section{GRAPHICAL ABSTRACT}

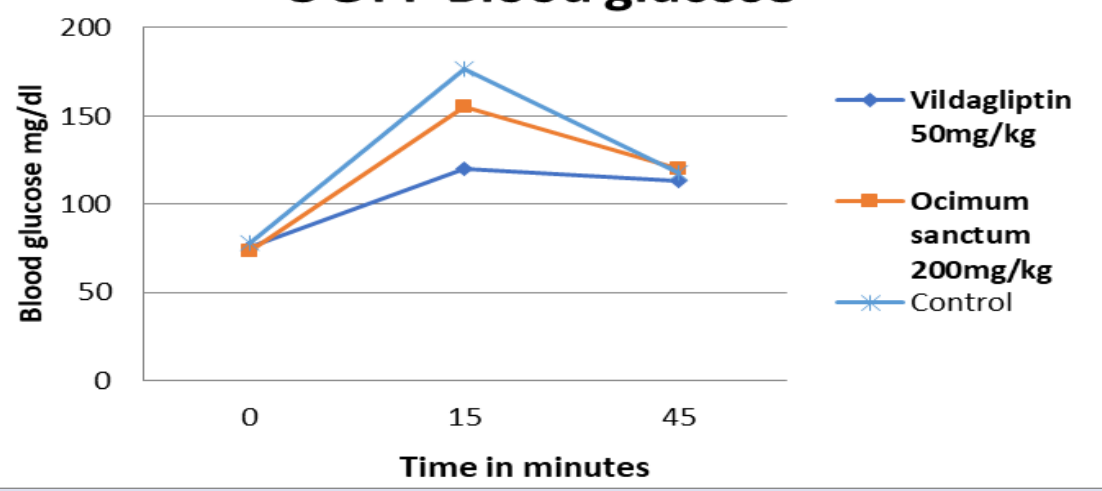




\section{ABOUT AUTHORS}

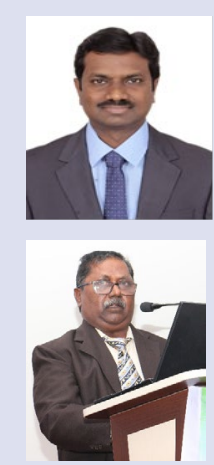

Dr. S. D. Inbaraj, MBBS, MD (Pharmacology) is a Research Scholar and Professor in department of Pharmacology, Sree Balaji Medical college and Hospital, Bharath Institute of Higher Education and Research [BIHER]. No 7 works road, Chromepet, Chennai- 600044 . Having more than 10 years of teaching experience in Pharmacology for undergraduate and post graduate medical students. Has vast experience in treating general as well as Diabetic patients. His research interest is in the field of edible herbs and their effect on incretins and diabetes mellitus.

Cite this article: Inbaraj SD, Muniappan M. Effect of Ocimum sanctum Leaf Extract on Entero-Insular Axis by Oral Glucose

Dr. M. Muniappan, MSc, PhD., retired Professor of Pharmacology, Sree Balaji Medical college and Hospital, Bharath Institute of Higher Education and Research [BIHER]. No.7 works road, Chromepet, Chennai- 600044 . Has more than 25 years of teaching experience in Pharmacology for undergraduate and post graduate medical students. Has guided many PhD scholars. His field of research is herbal medicines.

\section{Tolerance Test in Albino Rats. Pharmacog J. 2019;11(5):1138-42.}

